石油技術協会誌 第 20 卷 第 6 号（昭和 30 年11月）

JOURNAL OF THE JAPANESE ASSOCIATION OF PETROLEUM TECHNOLOGISTS

VOL. 20. NO. 6 (Nov., 1955)

\title{
ビットの掘進率に關する研究*
}

藤 井 清 光**

(昭和 30 年 10 月 1 日受理)

\section{Study on the Rate of Penetration of Rotary Bit}

By

\section{Kiyomitsu FUJII}

\begin{abstract}
Factors affecting the rate of penetration of a blade bit are measured by the use of a bit testing instrument.
\end{abstract}

\section{I. 緒 言}

北戸を掘る技術として，ロータリーの方法が行われる ようになつてから，地下深い所にある石油や天然ガスな ぞの開発が非常に容易になつた。特に石油が現在の産業 の非常に大きな部分を占めるようになつた原因の 1 つは ロータリー掘鳘によつて石油が経済的に開発されるよう になつたことである。しかしロータリー掘錅を技術的に 見ると, 種々の团難な問題が多数あるので, 経浡的に地 下資源を開発するという役割を，口ータリ一掘籢が今後 も続け得るかどらか，疑閤が発生する。特にわが国では 自然の条件に難しい点が多いので，口ータリ一掘警の将 来関しては，全く楽観が許されない。この困難を打開 する方法は, ビットと泥水の改善よりほかに方法はな い。开局を掘るのはビットと泥水（循環流体）とであつ て，その他の装置は補助的なものに過ぎないといつても 決してい〉過ぎではあるまい。このことは従来はとかく 忘れ勝ちに扱われてきたことである(泥水のことは，こ つでは論じない)。ビットに関しては浅い非戸を掘る場 合には，余り問題にする必要はなかつ心。しかし最近に なつて州户が梁くなるに従い,ビットの電要性が痛感さ れるようになつてきた。

このように, ビットは掘警の生命とい〉得るほど, 重 要なものであるにもかわわらず, ビットの掘錅作用の理 論関しては，今まではほとんど知られていなかつた。 それで井户を掘る場合には，経験に賴るよりほかに方法

\footnotetext{
* 交激省科学研究翼による研究, 昭和 30 年 5 月石油技乪染会總会に拾 ける個人譄演

** 慗京大学助蔽授
}

がなかつた。浅い井戸では一般に地畨は軟らかいので, このような原始的な態度でも，なんらさしつかえなかつ た。しかし䒠戸が深くなれば，このような方法は技術的 のみならず，経済的に許されない。今後はビットの掘籢 作用の理論に基づいて井戸を掘ることが，わが国のよう に経済的に苦しい立場にある所では, 絶対に必要なこと である。

以上のような理由によつて, 著者はビットの掘鳘作朋 の理論に関して研究を行つた。ロータリービットにはブ レード型とローラーカッター型とがあり, 浅い苏戸を除 いては，ローラーカッタービット（ロックビット）が主 として偊明される。ローラーカッタービットの作打は複 雑であるので，ビットの研究に関しては，まず簡笔な ブレードビットから始めることが順序であると考劣られ る。本文には, ブレードビットを使肼して, ビットの掘 進率に影響を与える項目について行つた基礎的な研究に 関して記す。

\section{II. 実験裝置および寸法}

実験隹湖した装置は第1 図江示すビット試験機であ る*。Aの部分に岩不を固定する。これは圧縮空気によ り上舁し，Bのビットに対し約 $1,000 \mathrm{~kg}$ の荷重を与え ることができる。荷車の值はCの目盛板から知ることが

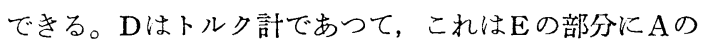
トルクを受ける装置があり，これから压力が伝わる。ビ ットの回転数は 1 分間に 30,60 执よび 120 に変化させ ることができる。

使用したビットは第 2 図に示されている。Cは材販の

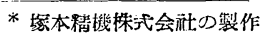


第 1 図

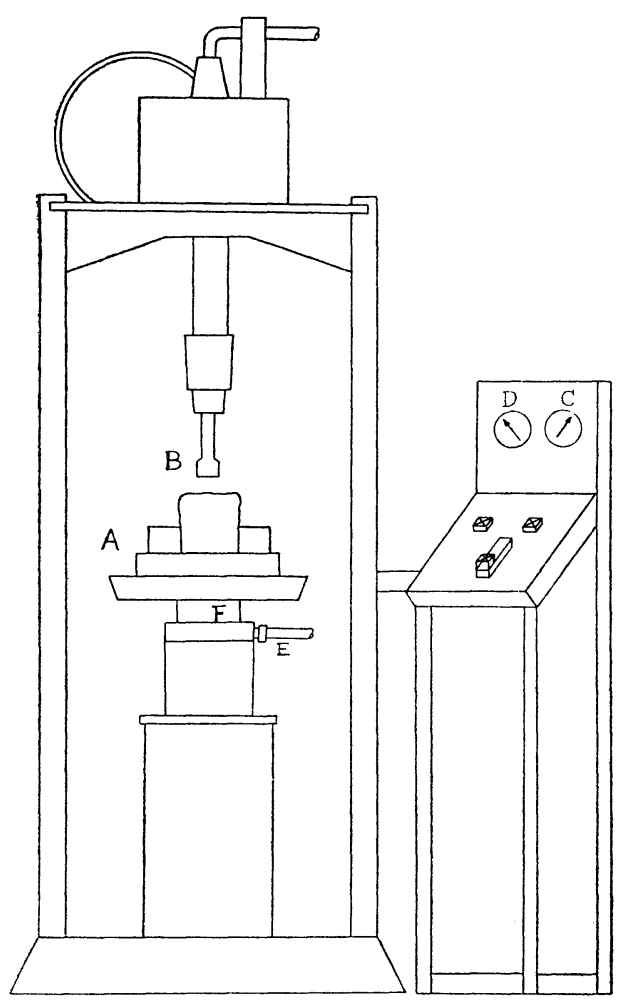

第 2 図

A
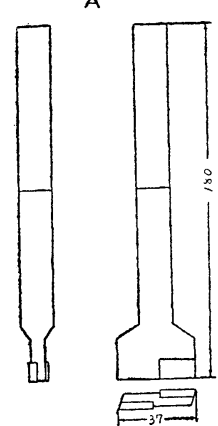

B

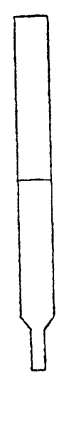

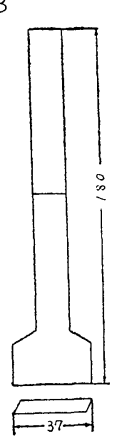

C

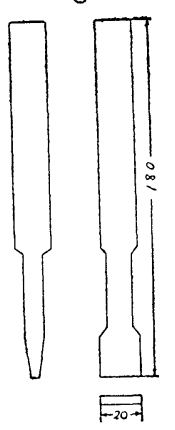

たがねを加工したものである。ショア一硬度は約 60 で ある。これは種々の双の厚さで実験に俌肞された。第 2 図Bは軟鋼でショアー硕度は約 25 である。これは実験 の最初に使用したが，橆耗が甚だしく笑験が时難である ので，Aのように炭化タングステンのチッブを植えたも のが，主として使胕されだ。

実験方法は, まず第1図のよ5にAに岩不を固定し，C により必要な荷乘をビットに対し与え, 必要な速さで回 転する。水または空気を管により外側からビットに吹き

*ビット B.C およびチツブは常国石油会社技衡研究所の製作

第 3 図

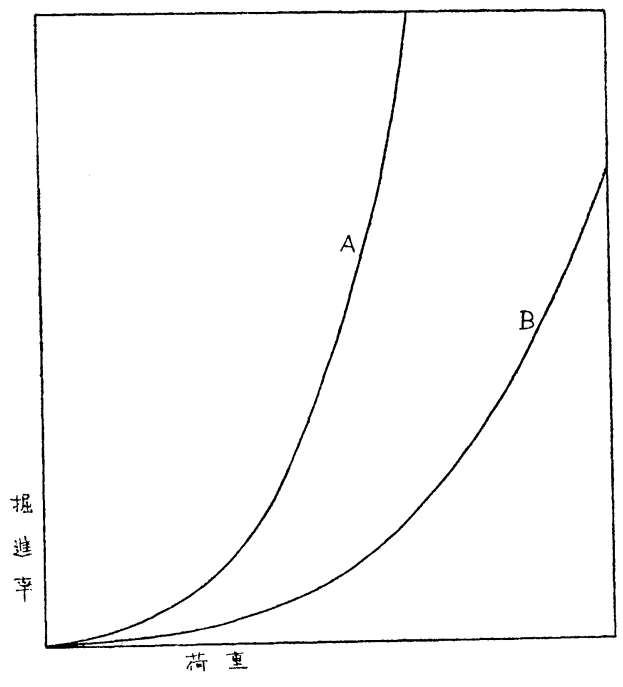

第 4 因

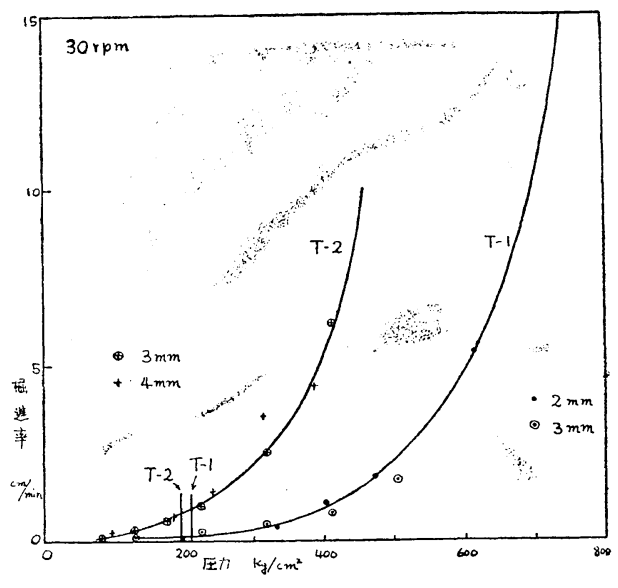

第 5 図

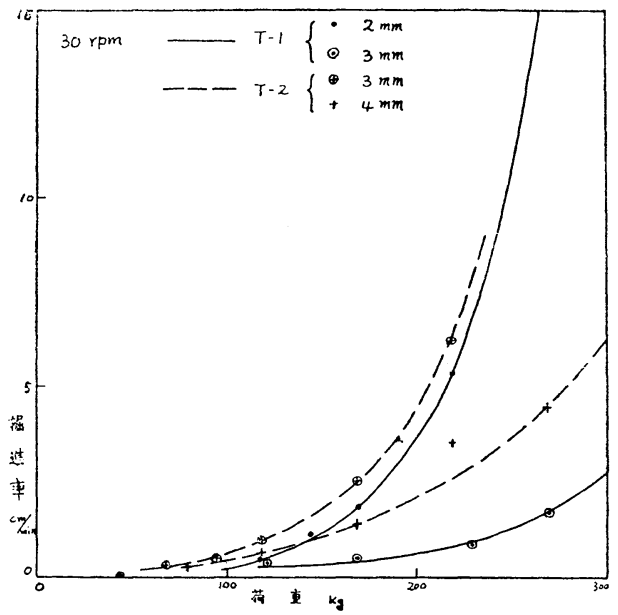


つけ，掘くずがたまらないようにする。1同の笑驗に掘 る泚さ治，石の種類により異なり，5〜20 mm である。 掘つた铱さはFにある目盛により知ることができる。笑

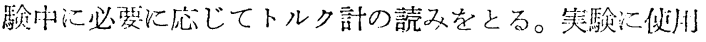
乙た不凝灭岩・砂岩・頁岩・安山岩・花崗岩などでむ る。このうち，大部分の石は地表から不材として採职さ れたさのであり，一部は来恶からコアーとして採られた ものである。

\section{III. 荷 重}

[问松数が一定の場合の荷重と掘進曼の関係は, 第 3 困 に示されている。これは一般的倾向を示しているのであ つて, 線Aのように荷重が小さい時は掘進摔が小さいが 街再が大きくなると掘進率は念に増加する。逆に荷雨が ある限度以下になると，掘進率は湾とんど 0 になる。B 總さAより硬い岩石の場合の関係を示している。もし同 じ不を优肞している場合には，Aの実験のビットより必 の厚さが厚いビットを使肘すれば，曲線はBのようにな る。こつで注意しなければならないのは，使䖝したビッ

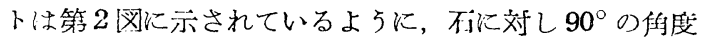

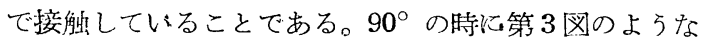
曲線になるのであつて, 角度が $90^{\circ}$ より大きくなれば曲 線の形は変わつてくる。しかし本交では, 角度が $90^{\circ}$ の ビットの実験結果に限定している。

2 種類の凝灭岩を使用して, 荷重と掘進率の関係を求 めたものが第 4 図である。この実験では掘くずを除くた めに经水が使打された。ビットは第2 図のCであり, 回 転数! 30 r.p m. である。ビットの必の厚さは $\mathrm{t}-1$ 凝 阮岩に対しては $2 \mathrm{~mm}$ および $8 \mathrm{~mm}, \mathrm{t}-2$ 凝灭岩に対し ては $3 \mathrm{~mm}$ および $4 \mathrm{~mm}$ である。ビットの直径はいず れも約 $17.5 \mathrm{~mm}$ である。第 4 图に上机ば同じ荷車を与 えても，不汇接触する面植が翼なれば，掘進率は暴な る。次に，この実験結果をビットに対する压打と掘進率 の関係として表わせば，第5図のようになる。これによ れば同じ不沉対しては, ビットが不化接触する面臌が翼

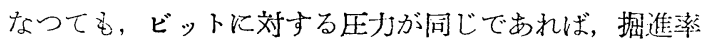
は同じになる。すなわちビットに対する区カが掘淮摔没 支配与る。

\section{IV. 岩石の性質}

岩不们種々の物理的性質のうち, 特にブレードビット

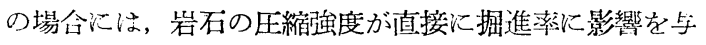
えると考えられる。第 4 図または第 5 図の実験に䏘いた 㠜炏岩の王縮強度は $\mathrm{t}-1$ は $206 \mathrm{~kg} / \mathrm{cm}^{2}$ であり, t-2 は $199 \mathrm{~kg} / \mathrm{cm}^{2}$ である。第5 図で明らかなように,ビットに 加える圧才が石の王縮強度以下の場合には, 掘進摔は非
常に小さいが，压力が不の圧縮运度を越えると，掘進率 は隹に増加する。このよ5にブレードビットの掘進率は，

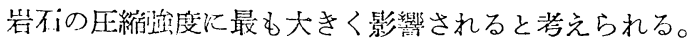

\section{V. 回 転 数}

ビットの问転数と掘進絜との関係は簡単なようで複雑 である。一般的にいえば掘進率性回転数に直線的に比例 する。しかし測定值はかなり広く散らばり，上の関係を 得るためには, 多くの実験結喿の平均值をとらなければ ならない。回転数の影笅は岩不の圧縮強度にも関倸があ るようで, ある種類の不は, 加兄る圧力が圧縮強度以下 の時に上の関係が成立し, ある種類の不では, 压縮強度 以上の压扎括いて上の関係が成立する。ビットの回転 に際して, 特殊の振動が発生する場合, あるいは掘くず が值らにとり去られないような状態にある場合には，直 線的関係は成立しない。

\section{VI. 磨 耗}

ビットに対して蒜局を大きくして掘進摔を大きくする

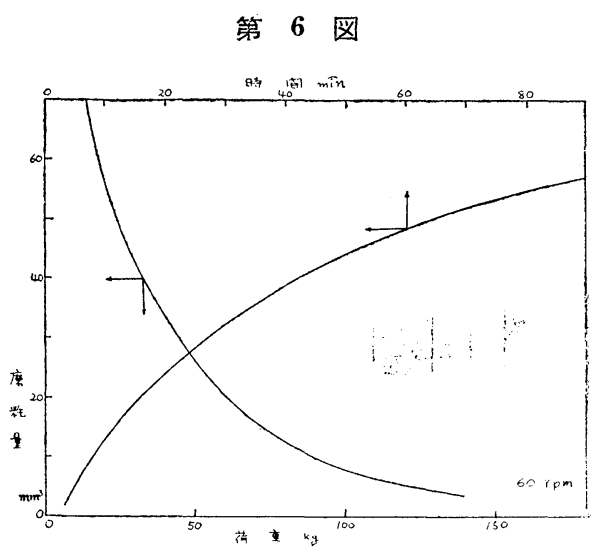

第 7 図

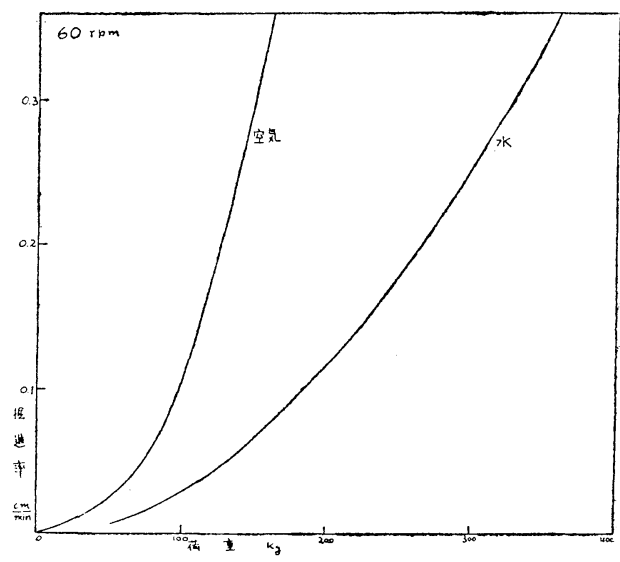


場全と, 小さい荷重で小さな掘進率で掘る場合とで, ど ららがビットの磨耗が大きいかということは，現場では 雨琵な問題である。凝灰岩を第 2 図Cのビットで拙つた 実駼繶棵は第 6 図である。ビットが不に接触する部分以 $13.3 \times 2.7 \mathrm{~mm}$ あり，回転数は 60 r.p.m.である。第 5 図によれば既耗量 $\left(\mathrm{mm}^{3}\right)$ はビットの加霟に反比例し, 掘鳘時間に比例している。これは大きな荷雷で北今学掘

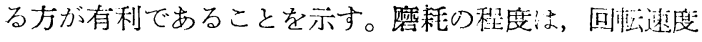
の関係から, 中心が一番小さく, 外側に行くに往つて大 きくなる。特に一番外侧の触はすぐ磨耗する。したがつ てビットの形は次第に中心が尖つてくる。

以上は炭化タングステンを使用しない場合である。闺 化タングステンを使用すれば，䎶らかい凝疢岩に対して は，数時間程度の実験では測定できないほど研耗量は 小さい。炭化タングステンをチップとしたものが鼠も通 く, 粉末をビットの裴面に熔青したものは, チップに比べ ればかなり弱い。しかしチップは笑際のビットに俌けし た場令には，脆いのでかけることが多いと考光られる。

\section{VII. 循環流体の種類}

以上の実験では掘くずを除くために水を俅封した。怨

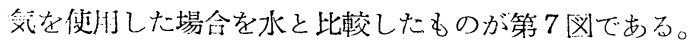

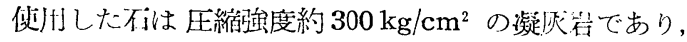
ビットは第2図Bで，不见接触する面積は約 $2.6 \mathrm{~cm}^{2}$ で ある。第7図によれば空気の方がかなり掘進摔が大き い。頁岩の場合にも似たよらな結果が出た。水を伐北し た時には，掘くずのなかに 1〜2 $\mathrm{mm}$ の大きさのかけら がかなり混るのに対し，空気を使打した時には，掘くず がすすべて 100 ×ッシュ以下になる点が著しい邀いであ る。以上の結果から，湖肘する流体の種類により，不の 粒子の結合状態が晎なることが掘進率の洷の原团と考え られる。したがつて空気の方が掘進率が大きいといらこ とは，すべての不にあてはまるのではなく，特䇥の不の 種洸のみに限定されるものと考えられる。

\section{VIII. 他の研究亡の比較}

ビットの掘進率に関して，本文の実駼結梀を外非の研 究と比較すると以下のようになる。たぶし外国の研究は すべてロックビットに関して行われたものである。掘進

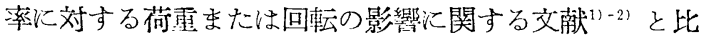
較すると，本交の実験結果は非常に似た倾面になつてい る。ブレードビットの実験結果が，ローラーカッタービ ットの結果と似ていることは，注目すべきことである。 特に Hughes 会社の研究"では，次のよ5な式を临し てている。

掘進率= (回転数 $) \times($ ビット 1 in 当り獄車 $)$ K
Kは岩不の種粸によつて 1〜2.3の籍围にむる。この 関係式は研究所の舆験装琵によつて得たものである。実 際の掘籢においては，必ずしもこの通りにならず，回転 数を 2 佔にしても，掘進率は $50 \%$ しか増加しないこと がある。この原团は泥水の㧓環量が足りないためであ る。したがつて上の関係が成立するためには，掘くずが 北宁の供にたまらないように，一个分な泥水を送る必琹が ある。以上から，荷雨または可転を増加することととも に, 泥水の很㵙量を増加させなければ然意味であること が明らかとなる。

ロックビットの㮯耗に関しても，本文の実駼と同じよ うな結檕が代ている2゙。すなわち1つのビットが掘り得 る長さは, 荷雨の增加によつて著しく長くなる。このこ

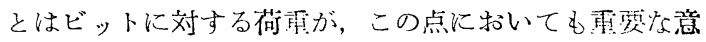
味を窂すことを明らか汇している。

\section{IX. 結 論}

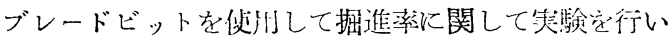
種々の結喿を得た。この研究は現在でも継続されている ものであつて，まだ鼠終的結論を得ていないが，哯在ま でに笑跧されて得た結照は，大体次のよ5なものであ zo

（1）回坃数が二定の場合に，ビットに対与を荷雷が

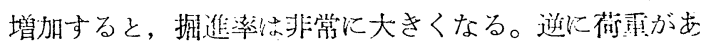
る限度以下沉なると，掘進率はほとんど0になる。

（2）回枟数が一定の場合には，ビットに対与る恃む が掘進摔淁㚆配する。

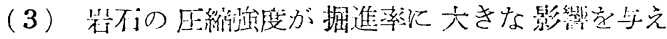
\%。

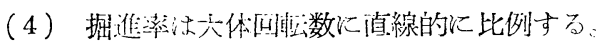

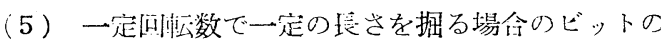
眯耗量は，六体時间に比例する。したがつてビットに対 する荷雨が小いと，碅耗冲大きい。

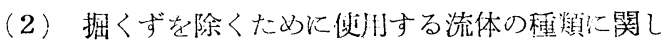

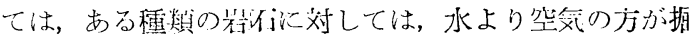
進率は大きい。

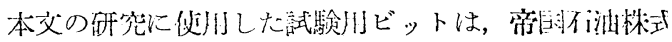
会社技術仾究听から提供されたものを含んでいる。実粘 恃柬大採沺研突空の佐藤光大助手の驽力によるものが多 い。こ〉に感謝の意を表わす次第である。

\section{参考文献}

1) R. A. Bobo, R. S. Hoch and G. S. Ormsby : Keys to Successful Competitive Drilling, Worl, Oil, March, 1955.

2) W. M. Booth : Weight on Bit and Rotary Speed, Petroleum Engineer, April, 1955. 